\title{
RESERVE FOOD MATERIALS IN VEGETATIVE TISSUES
}

Gwynethe M. Tuttele

In view of the importance of the distribution of starch and fats as food reserve substances in vegetable tissues, and its connection with investigations regarding the effect of low temperatures on cells, it was thought desirable to investigate the conditions prevailing in some trees and shrubs of northern Alberta. Observations by several investigators have been made from other regions in the north temperate belt, such as those of Lidforss (3), Mryake (4), and Sinnotr (5) from Sweden, Japan, and eastern United States respectively. All of these districts lie between the winter isotherms of $30^{\circ}$ and $40^{\circ} \mathrm{F}$., whereas northern Alberta lies between those of $10^{\circ}$ and $20^{\circ} \mathrm{F}$. (I). Furthermore, vegetation in this region is frequently subjected to short periods of very low temperatures during the winter months, reaching $-50^{\circ} \mathrm{F}$., which makes the problem of resistance to cold a very important one.

LIDFORSs found that all "winter green" leaves are free from starch, but contain sugar and sometimes oil in winter. The starch is replaced by sugar during November, while the reverse change takes place in April. These results were largely confirmed for this region. Much of the material examined by SinNotT retained starch as a food reserve throughout the winter, although many of the species were characterized by an oily reserve. $\mathrm{He}$ found that starch was most common in regions remote from the conducting channels, and fat most abundant in and near the phloem, close to the vessels. His "starch" trees were characterized by thick, squarish medullary ray cells with strongly lignified and small pitted walls; while the "fat" trees showed medullary ray cells with thin or unlignified walls and large pits. This he interpreted as indicating that "the character of the food reserve in any cell depends primarily upon the ease with which water, or substances carried by water, have access to the cell. Where the movement is apparently slow and difficult, the reserve persists as 
starch; where such movement is easy, starch disappears at the beginning of winter and fat is produced."

A representative number of trees, shrubs, and perennial herbaceous plants of the region round Edmonton were examined. As the number of native plants with "winter green" leaves was very limited, tests of the stems of the deciduous types were included in the observations. Sections of the leaf, stem, and bud were tested with iodine solution and osmic acid at intervals from October to June. Records extending over three seasons show very little variation during October. Starch was quite abundant in the medullary ray cells, phloem, and cortex. Oils and fats were present in nearly all cells of the phloem and cortex and in the medullary ray cells of some plants. In several cases cortical cells contained food reserve which did not react to either iodine or osmic acid, suggesting the "transitory substance" mentioned by Sinnotr. Various tests were applied, but the identity of the substance was not determined. Some of the material was tested microchemically for sugar by means of the Flückiger reaction (6). Heavy precipitates of cuprous oxide were obtained (on heating) in Syringa, Populus, Prunus, Salix, Shepherdia, Ribes, Picea, Pinus, Rosa, Pyrola, Cornus, and Eleagnus, indicating the presence of glucose and dextrins. A positive determination of sugars could not be obtained by this means, on account of the possibility of the presence of a large number of other reducing substances in the cells; and in the absence of a satisfactory microchemical test for sugars, the work was not continued. Quantitative determinations of the sugar contents of a few cell saps made in another investigation have been recorded (2), where it was found that the total sugars varied from 0.5 to 2 per cent. The condition of the starch and oil reserve, tested at different seasons, is shown in table I.

In the majority of cases starch disappeared from the local plants during October and early November. Oils and fats were abundant in all of the species examined, with the exception of Lonicera and Crataegus. In view of the fact that a few species showed a trace of starch in their tissues quite late in winter, anatomical examinations were made and the two types described by SiNNOTT 
as "fat" and "starch" trees were recognized. Those species which retained small quantities of starch corresponded in all cases to the structure of "starch" trees, whereas those in which conversion was most rapid were of the "fat" tree type. Although species which retained definite starch reserve during the winter are absent from this locality, certain of the facts seemed to give limited support to the

TABLE I

\begin{tabular}{|c|c|c|c|c|}
\hline Material & October & December & February & May \\
\hline Populus tremuloides. . . . . . . . . . & $\mathrm{S}$ and $\mathrm{O}$ & $\mathrm{O}$ & $\mathrm{O}$ & $\mathrm{S}$ and $\mathrm{O}$ \\
\hline Populus balsamifera........... & $\mathrm{S}$ and $\mathrm{O}$ & $\mathrm{O}$ & $\mathrm{O}$ & $\ldots \ldots \ldots \ldots$ \\
\hline Salix rubra............... & $\mathrm{S}$ and $\mathrm{O}$ & $\mathrm{O}$ & $\mathrm{O}$ & \\
\hline Shepherdia canadense......... & $\mathrm{S}$ and $\mathrm{O}$ & $\mathrm{O}$ & $\mathrm{O}$ & $\mathrm{S}$ and $\mathrm{O}$ \\
\hline Betula subcordata $\ldots \ldots \ldots \ldots$ & $\mathrm{S}$ and $\mathrm{O}$ & & $\mathrm{O}$ & \\
\hline Amelanchier alnifolia.......... & $\mathrm{S}$ and $\mathrm{O}$ & & $\mathrm{O}$ & $\mathrm{S}$ and $\mathrm{O}$ \\
\hline 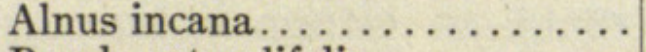 & $\mathrm{S}$ and $\mathrm{O}$ & & $\mathrm{O}$ & $\mathrm{S}$ and $\mathrm{O}$ \\
\hline Pyrola rotundifolia ........... & SS and $\mathrm{O}$ & $\mathrm{O}$ & $\mathrm{O}$ & $\mathrm{O}$ \\
\hline Cornus canadensis............ & $\mathrm{O}$ & $\mathrm{O}$ & $\mathrm{O}$ & $\mathrm{O}$ \\
\hline Linnaea borealis var. americana. & SS and $\mathrm{O}$ & $\mathrm{O}$ & $\mathrm{O}$ & $\mathrm{O}$ \\
\hline Mitella nuda ............... & $\mathrm{SS}$ and $\mathrm{O}$ & $\mathrm{O}$ & $\mathrm{O}$ & \\
\hline Corylus rostrata $\ldots \ldots \ldots \ldots \ldots \ldots$ & $\mathrm{S}$ and $\mathrm{O}$ & & $\mathrm{O}$ & $\mathrm{S}$ and \\
\hline Picea canadensis. . . . . . . . . & $\mathrm{SS}$ and $\mathrm{O}$ & $\mathrm{O}$ & $\mathrm{O}$ & $\cdots \cdots \cdots$ \\
\hline 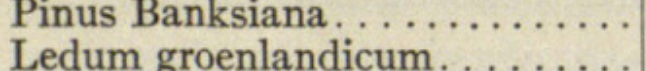 & Sond & $\mathrm{O}$ & $\mathrm{O}$ & \\
\hline Arctostaphylos Uva-ursi........... & O & $\mathrm{O}$ & $\ddot{\mathrm{O}}$ & $\mathrm{S}$ and $\mathrm{O}$ \\
\hline Vaccinium Vitis-Idaea......... & $\mathrm{SS}$ and $\mathrm{O}$ & & & \\
\hline Viburnum pauciflorum........ & $\mathrm{S}$ and $\mathrm{O}$ & $\mathrm{O}$ & $\mathrm{O}$ & $\mathrm{S}$ and $\mathrm{O}$ \\
\hline Prunus pennsylvanica.......... & $\mathrm{S}$ and $\mathrm{O}$ & $\mathrm{O}$ & $\mathrm{O}$ & \\
\hline Ribes setosum. . . : $\cdots \cdots \cdots \cdots$ & $\mathrm{S}$ and $\mathrm{O}$ & $\mathrm{SS}$ and $\mathrm{O}$ & SS and $\mathrm{O}$ & \\
\hline Symphoricarpos occidentalis.... & $\mathrm{S}$ and $\mathrm{O}$ & $\mathrm{SS}$ and $\mathrm{O}$ & SS and $\mathrm{O}$ & $\mathrm{S}$ and $\mathrm{O}$ \\
\hline Rosa arkansana............... & $\mathrm{S}$ and $\mathrm{O}$ & $\mathrm{SS}$ and $\mathrm{O}$ & $\mathrm{SS}$ and $\mathrm{O}$ & $\mathrm{S}$ and $\mathrm{O}$ \\
\hline Eleagnus argentea ........... & $\mathrm{S}$ and $\mathrm{O}$ & SS and $\mathrm{O}$ & $\mathrm{O}$ & $\mathrm{S}$ and $\mathrm{O}$ \\
\hline Cornus stolonifera . ........... & $\mathrm{S}$ and $\mathrm{O}$ & SS and $\mathrm{O}$ & $\mathrm{O}$ & $\mathrm{S}$ and $\mathrm{O}$ \\
\hline Crataegus tomentosa..$\ldots \ldots \ldots \ldots$ & $\mathrm{S}$ and $\mathrm{O}$ & SS and $\mathrm{O}$ & $\mathrm{O}$ & $\mathrm{S}$ and $\mathrm{O}$ \\
\hline 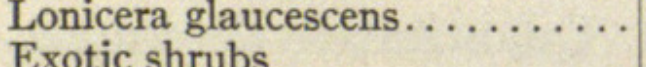 & & $\mathrm{S}$ & $\cdots \cdots \cdots \cdots$ & \\
\hline Syringa vulgaris... & $\mathrm{S}$ and $\mathrm{O}$ & $\mathrm{SS}$ and $\mathrm{O}$ & $\mathrm{O}$ & SS and $\mathrm{O}$ \\
\hline Carragana sp.............. & & SS & No starch & $\mathrm{S}$ \\
\hline Ribes sp................ & $\mathrm{S}$ and $\mathrm{O}$ & SS and $\mathrm{O}$ & & \\
\hline Acer Negundo............ & $\mathrm{S}$ and $\mathrm{O}$ & $\mathrm{SS}$ and $\mathrm{O}$ & SS and $\mathrm{O}$ & \\
\hline
\end{tabular}

$\mathrm{S}$, starch; SS, slight starch reaction; $\mathrm{O}$, oils and fats.

view recently suggested by SinNotT in regard to the relation of structure to the nature of food reserve.

Tests were made of the leaves of the majority of the local deciduous trees and shrubs at the time of leaf fall. The I $_{5}$ species examined were characterized by the absence of starch, except in 
Ribes and Cormus, which were found to contain minute quantities, whereas all showed a relatively high oil and fat content. The winter buds of the same trees showed a high percentage of starch at this time. It would seem that the starch had either been converted in the mature leaves before leaf fall or else translocated to other regions of the plant. Table II records the leaf material tested.

TABLE II

MATERIAL

Symphoricarpos sp.

-Symphoricarpos occidentális

Ribes sp.

Ribes setosum

Betula subcordata

Rubus sp.

Corylus rostrata

Fragaria sp.

Corydalis sp.

Ledum groenlandicum

Arctostaphylos Uva-ursi

Vaccinium Vitis-Idaea

Syringa vulgaris

Cornus stolonifera
FOOD RESERVE

Oils and fats

Oils and fats

Oils and fats

Trace of starch

Oils and fats

Oils and fats

Oils and fats

Oils and fats

Oils and fats

Oils and fats

Oils and fats

Oils and fats

Trace of starch

Oils and fats

Several species of Salicaceae and Ericaceae were examined from high elevations in the mountains of Alberta and British Columbia, with a view to determining any difference in food reserve due to the different habitat. Herbarium specimens were used for the tests as fresh material was not obtainable. As these had been quickly and carefully dried, there is no reason to suppose that the starch or fat content of the cells would have been affected. Material of the stem was softened in water and tested immediately. Very definite reactions were obtained. Most of the material had been collected at the height of the vegetative season for the elevations at which it occurred. It was not possible to establish any connection between high elevation and a difference of food reserve. The majority of the species examined showed the presence of both starch and oil during the vegetative season, although a few contained only oil, as shown in table III. 
TABLE III

MATERIAL

Salix glaucops
Salix nivalis
Salix herbacea
Phyllodoce empetriform
Kalmia glauca
Phyllodoce glanduliflora
Arctostaphylos Uva-urs
Ledum groenlandicum
Rhododendron albifloru
Menziesia glabella
Vaccinium scoparium
Arctostaphylos alpina
Arctostaphylos alpina
Cassiope Mertensiana
Salix vestita
Salix arctica
Gaultheria ovatifolia
Arctuous erythrocarpa
Empetrum nigrum

$$
\begin{gathered}
\text { Elevation } \\
\text { IN FT. }
\end{gathered}
$$

\section{Starch and oil present}

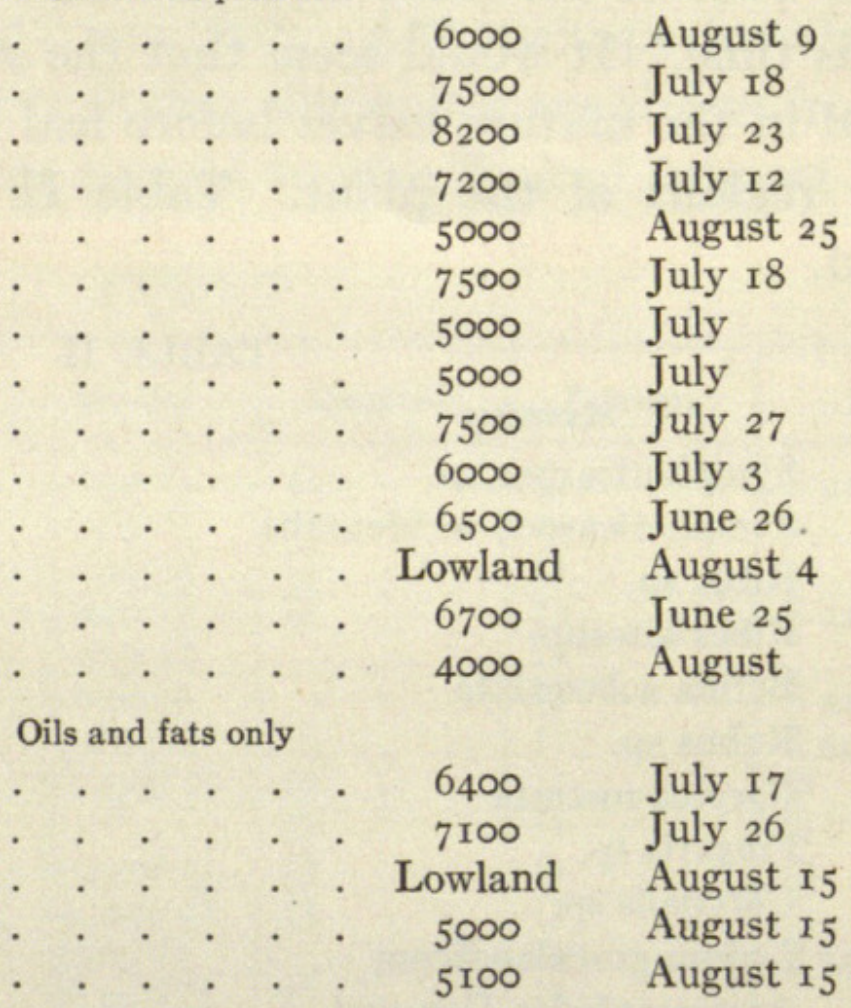

\section{Summary}

I. All the species examined showed a high starch content during the summer, which disappeared during October.

2. All the trees and shrubs of this district which were examined contained oils and fats as food reserve during winter with the exception of Lonicera glaucescens and Crataegus sp. The presence of sugar was demonstrated in many of the species. Quantitative determinations in a few places gave a total sugar content of $0.5^{-2}$ per cent.

3. Deciduous leaves, at the time of leaf fall, were devoid of starch, but contained oils and fats.

4. Most of the species of alpine Salicaceae and Ericaceae examined showed the presence of both starch and oil during the vegetative season. Gaultheria ovatifolia, a lowland species, showed only oil. Hence the ability to form starch does not seem to be associated with climatic conditions, resulting from high altitudes. 


\section{LITERATURE CITED}

I. Bartholomew, J. G., Physical atlas, vol. 3. I899.

2. Lewis, F. J., and Tutrle, Gwynethe M., Osmotic properties of some plant cells at low temperatures. Ann. Botany 34:405-416. 1920.

3. Lidforss, B., Die wintergrüne Flora. Lunds Universitets Arsskrift 2: no. 13.1907.

4. Mryake, KUCHI, On the starch of evergreen leaves and its relation to photosynthesis during the winter. Bот. GAz. 33:321-340. 1902.

5. Sinnoti, E. W., Factors determining the character and distribution of food reserve in woody plants. Вот. GAz. 66:162-175. I9I8.

6. Tunmann, O., Pflanzenmikrochemie. I9r3. 


\section{$2 \mathrm{BHL}$ Biodiversity Heritage Library}

Tuttle, Gwynethe M. 1921. "Reserve Food Materials in Vegetative Tissues." Botanical gazette 71(2), 146-151. https://doi.org/10.1086/332807.

View This Item Online: https://www.biodiversitylibrary.org/item/109572

DOI: https://doi.org/10.1086/332807

Permalink: https://www.biodiversitylibrary.org/partpdf/224250

\section{Holding Institution}

Missouri Botanical Garden, Peter H. Raven Library

\section{Sponsored by}

Missouri Botanical Garden

\section{Copyright \& Reuse}

Copyright Status: Public domain. The BHL considers that this work is no longer under copyright protection.

This document was created from content at the Biodiversity Heritage Library, the world's largest open access digital library for biodiversity literature and archives. Visit BHL at https://www.biodiversitylibrary.org. 